\title{
Weedy rice in sustainable rice production. A review
}

\author{
Sadia Nadir ${ }^{1,2,3} \cdot$ Hai-Bo Xiong ${ }^{1} \cdot$ Qian Zhu $^{1} \cdot$ Xiao-Ling Zhang $^{1} \cdot$ Hong-Yun Xu ${ }^{1}$ • \\ Juan $\mathrm{Li}^{1}$ • Wenhua Dongchen ${ }^{1}$ - Doku Henry ${ }^{1} \cdot$ Xiao-Qiong Guo ${ }^{1} \cdot$ Sehroon Khan $^{4,5}$. \\ Hak-Soo Suh ${ }^{6}$ Dong Sun Lee ${ }^{1,3} \cdot$ Li-Juan Chen ${ }^{1,3}$
}

Accepted: 29 August 2017 / Published online: 30 September 2017

(C) The Author(s) 2017. This article is an open access publication

\begin{abstract}
Weedy rice refers to the unwanted plants of the genus Oryza that have some undesirable agronomic traits and pose a major threat to sustainable rice production worldwide. Widespread adoption of direct seeded rice and hybridization or gene flow between cultivated rice and their wild relatives has resulted in the creation and dissemination of weedy rice. Currently, weedy rice (Oryza sativa f. spontanea) has become one of the most common weeds infesting rice fields worldwide. In this paper, we review the biology, physiology, evolution, and genetic features of weedy rice. We also discuss the major obstacles in weedy rice management, including high diversity of weedy rice, ecological impacts of gene flow on weedy rice, changing climate, and weedy rice management. We then present a framework for the sustainable management and utilization of weedy rice. Our main emphasis
\end{abstract}

Dong Sun Lee

dong_east@hanmail.net

$\checkmark$ Li-Juan Chen

964136487@qq.com

1 State Key Laboratory for Conservation and Utilization of Bio-Resources in Yunnan, Yunnan Agricultural University, Kunming, Yunnan 650201, China

2 Department of Chemistry, University of Science and Technology, Bannu, Khyber Pakhtunkhwa, Pakistan

3 Rice Research Institute, Yunnan Agriculture University, Kunming, Yunnan 650201, China

4 Key Laboratory of Economic Plants and Biotechnology, Kunming Institute of Botany, Chinese Academy of Sciences,

Kunming, Yunnan 650201, China

5 World Agroforestry Centre, East and Central Asia, Kunming, Yunnan 650201, China

6 School of Biological Resources, College of Natural Resources, Yeungnam University, Kyongsan 712-749, South Korea is to explore the reservoir of natural variations in weedy germplasm and to utilize them for crop improvement. This review outlines some of the latest biotechnological tools to dissect the genetic backgrounds of several favorable traits of weedy rice that may prove beneficial for breeding and evolutionary studies on cultivated rice. We suggest that by merging the disciplines of genomics, breeding, and weed management, we can achieve the goal of sustainable rice production.

Keywords Weedy rice $\cdot$ Climate change $\cdot$ Stress tolerance . Biotechnology $\cdot$ Biocontrol

\section{Contents}

1. Introduction

2. Origin and evolution

3. Distribution and genetic differentiation

4. Gene flow and its associated concerns in weedy rice

5. Adaptive evolutionary traits of weedy rice

5.1 Seed dormancy

5.2 Seed shattering

5.3 Red pericarp color

5.4 Stress tolerance

6. Strategies to control and manage weedy rice

7. Potential value of weedy rice

8. Future outlook

9. Conclusion

\section{Introduction}

Rice is an important nutritional resource and is globally grown on about 153 million hectares of land, $90 \%$ of which is in Asia (Chauhan 2013). About 350 species of different genera, including seven species of Oryza, have been reported as weeds 
of rice (Holm et al. 1979; Smith 1981). Weedy rice includes all unwanted weedy populations of the genus Oryza growing in and around rice fields (Fig. 1). Weedy rice is also referred to as "red rice" because of its red pericarp. However, weedy rice biotypes with white, light red, and light green pericarps are also found (Prathepha 2009). In addition, there are many grain cultivars with the red grain phenotype. Therefore, the term weedy rice is more appropriate than red rice (Chen and Suh 2015). The characteristic features of weedy rice are taller height, ease of shattering, strong seed dormancy, and often a pigmented aleuronic layer (Fig. 1). The critical weedy traits of grain shattering and seed dormancy lead to harvest losses and a large soil seed reservoir in future years. The ability of weedy rice to thrive in adverse agro-environmental conditions and to imitate cultivars renders it difficult to control by simple means.

The traditional rice cultivation method is flooding the fields, which is labor intensive and requires considerable supplies of water. Due to manpower limitations and the problematic water management of traditional puddled rice transplantation, rice cultivation practices have increasingly switched to direct seeded rice (DSR) (Ali et al. 2014; Ziska et al. 2015). Direct seeded rice technology (wet, dry, or water seeding) has a positive effect on yield, requires less labor, and has a reduced water management requirement (Ali et al. 2014). However, infestations of rice fields with weeds have become a significant problem since the adoption of DSR, because of the absence of the suppressive effect of flooding on the weeds that emerge either before or along with the rice crop (Chauhan 2013). If not controlled effectively, weed infestations can cause severe economic losses by decreasing the quality and yield of rice (Singh et al. 2006). Weed-induced yield losses can be as high as $100 \%$ under DSR conditions (Rao et al. 2007). The rice monocropping system also provides a suitable environment for weedy rice growth. Weedy rice infestations and yield losses have been reported from many parts of the world. Weedy rice infestation rates in European and US rice fields are estimated to be 30 and $70 \%$, respectively (Gealy 2005; Català et al. 2002). Previous research has suggested that about $80 \%$ of rice fields are infested by weedy rice in Cuba (Baek and Chung 2012) and about 50\% of the rice fields in Senegal, West Africa, are reported to be affected with weedy rice biotypes (Diallo 1999). According to Azmi et al. (2000), weedy rice caused yield losses of up to $74 \%$ in Malaysia. If weedy rice-induced losses cannot not be controlled, they could adversely affect food security as well as the global economy.

Due to the adoption of DSR and the reduced manpower involvement in rice cultivation, weedy rice has spread vigorously in many rice-planting areas in China, particularly in the Northeast and Hainan, Guangdong, and Jiangsu Provinces. According to one estimate, DSR is practiced in about $15 \%$ of rice-planting areas in China (Yao 2012). It is thought that
3 million hectares of Chinese rice fields have been infested with weedy rice, leading to a yield loss of about 3.4 million tonnes per year (Rathore et al. 2016). Sun et al. (2013) reported that weedy rice has infested approximately 600,000 ha of rice-growing fields in Northeast China.

Different weed control measures are practiced in rice cropping to minimize weedy rice infestations and subsequent yield losses. Planting herbicide-resistant seeds was thought to eliminate weedy rice problems, but the emergence of herbicide-resistance among the weeds generated more severe issues by making weeds more competitive (Bhatia and Mitra 2003; Lu and Snow 2005), and climate change is predicted to worsen weed management in rice cropping (Rodenburg et al. 2010; Ziska et al. 2012). Appropriate management and control of weedy rice can only be achieved by an integrated approach that includes both basic and advanced methods. In addition, increased awareness about the ecophysiology and diversity of weedy rice on a local and community level, recognition of knowledge frameworks, and innovations in science and technology are required to identify the challenges and opportunities facing rice cultivation. There are many diverse challenges affecting weed control, but a wide range of options to meet development and sustainability in rice cropping are available. Weedy rice is congeneric and conspecific to cultivated rice, and it promotes crop-weed hybridization and the introgression of traits, such as herbicide resistance. Thus, it can tolerate stress conditions better than the current cultivars (Suh 2003). Weedy rice grains show high diversity in biochemical components, including amylose and protein contents and antioxidants (Chen and Suh 2015). Weedy rice has been reported to adapt and survive in a particular habitat for many years, and this trait could play an important role in evolutionary studies on cultivated rice (Chen and Suh 2015).

In this review, we discuss the evolution, distribution, physiology, and genetics of weedy rice. We focus on the beneficial traits of weedy rice and suggest that these may be exploited to construct new varieties of high-yielding domesticated rice with considerable resistance against disease and abiotic stresses.

\section{Origin and evolution}

The genus Oryza includes more than 20 wild species but only two species Oryza sativa (Asian rice) and Oryza glaberrima (African rice) are domesticated (Aggarval et al. 1997; Ferrero 2003). O. sativa has been differentiated into indica, japonica, and javanica varieties (Olofsdotter et al. 2000). Weedy rice (O. sativa f. spontanea) is taxonomically classified as the same species as cultivated rice (Tang and Morishima 1997). Apart from O. sativa f. spontanea, the wild ancestors of cultivated rice, such as Oryza rufipogon Griff., Oryza barthii A. Chev., and 
Fig. 1 Occurrence and characteristics of weedy rice. Occurrence and morphological variation of weedy rice grown in rice fields of a Myanmar, $\mathbf{b}$

Malaysia, c Nepal, d Korea, e Sri Lanka, and f China.

Characteristics of weedy rice: $\mathbf{g}$ easy seed shattering, $\mathbf{h}$ pericarp color, and $\mathbf{i}$ weedy rice panicles showing variations in awns, hull color, and panicle size
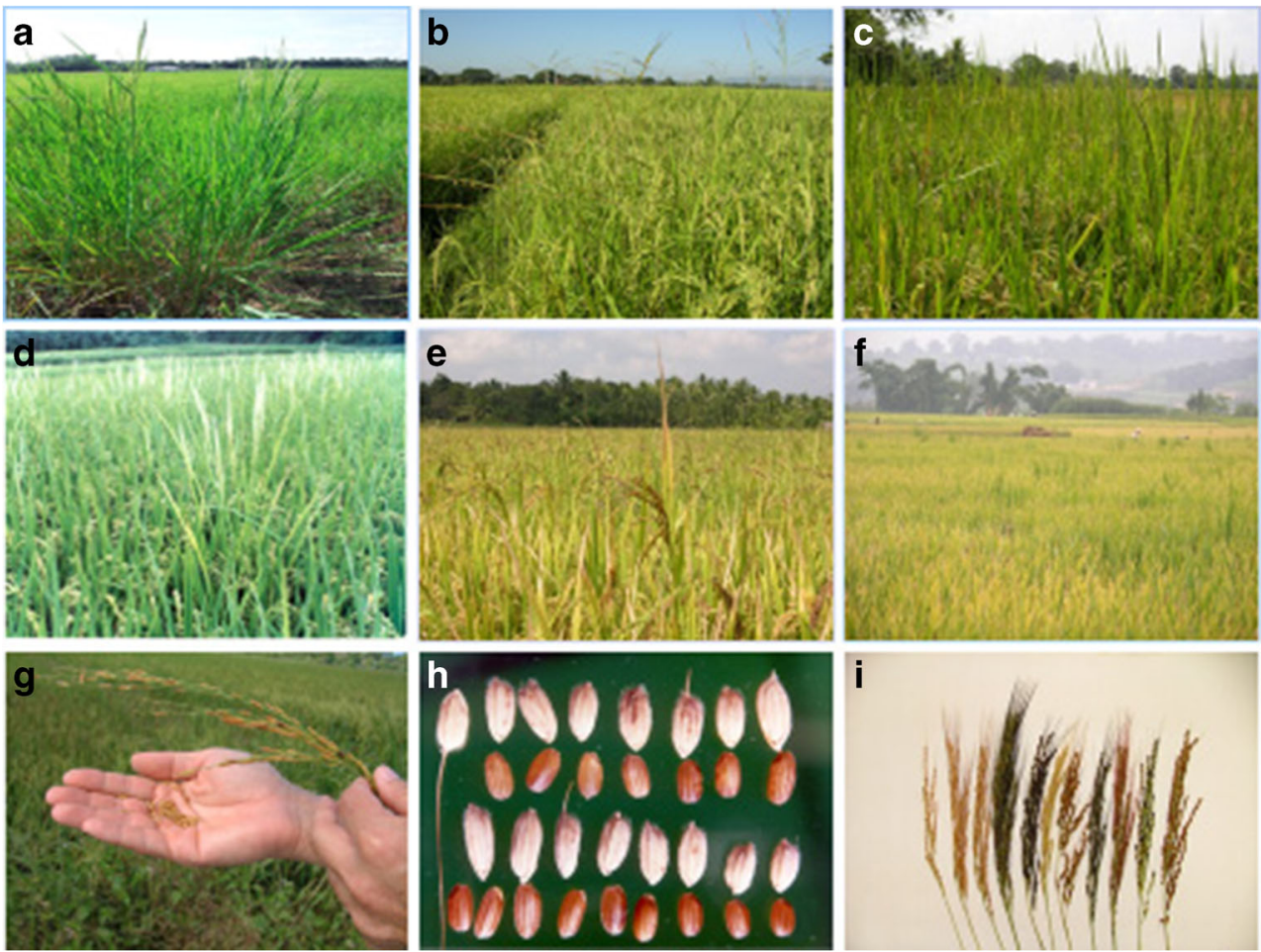

Oryza nivara S.D. Sharma \& Shastry, are important weeds in various rice-growing regions. Weedy rice is generally classified as $O$. sativa var. sylvatica in Italy (Ferrero and Vidotto 1998). The origin of weedy rice is controversial (Ellstrand et al. 2010), and a number of hypotheses have been suggested regarding the evolution of weedy rice. According to De-Wet and Harlan (1975), weedy rice originated from the selection and adaptation of wild rice to agricultural habitats. In regions where no wild rice has been grown, weedy rice may instead originate from cultivated rice through de-domestication with adaptive mutations and the accumulation of beneficial mutants (Ishikawa et al. 2005; Cao et al. 2006; Reagon et al. 2011; Thurber et al. 2010; Xia et al. 2011; He et al. 2014; Qiu et al. 2014; Lu et al. 2016; Li et al. 2017; Qiu et al. 2017). In the case of Brazil and Italy, where no wild Oryza types are indigenous, contamination of seed stocks with wild Oryza species has been proposed as a source of weedy rice (Carney 2004; Grimm 2014). Other hypotheses involve "hybridization or gene flow" between cultivated rice and their wild relatives (Londo and Schaal 2007) and/or inter-cultivar hybridization (Arashi 1974; Chen and Suh 2015). The close phylogenetic origin of the weedy forms to that of cultivated rice supports the hybridization and/or de-domestication hypotheses (Fig. 2a, b) (Ferrero 2003; Li et al. 2017). A recent study on genome-wide SNPs and domesticationrelated genes demonstrated that the weedy rice strains in the USA evolved from the de-domestication of cultivated ancestors; weediness could than emerge through selection of relatively few genomic regions ( $\mathrm{Li}$ et al. 2017). Studies in California have suggested that hybridization between japonica varieties may be a possible route for the origins of weedy rice (Ziska et al. 2015). Various studies on the origins of weedy rice that have been based on interfertility experiments, isozyme analysis, DNA similarity, and domestication-related traits have suggested that some weedy rice strains probably originated as a result of gene flow between wild and cultivated rice (Oka 1988; Sato 2000; Suh et al. 1997; Gealy et al. 2003; ArrietaEspinoza et al. 2005). In some regions of China, the weedy rice strains are closely related to locally grown cultivars rather than the wild rice O. rufipogon, which suggests that Chinese weedy rice probably originated from domesticated cultivars and hybrid rice volunteers (Cao et al. 2006, Zhang et al. 2014, Chen and Suh 2015). Phylogenetic and demographic analysis based on whole-genome sequencing revealed that Chinese weedy rice was de-domesticated independently from the cultivated rice, standing variations and new mutations contributed differently to the rapid adaptation of japonica and indica type of weedy rice from four representative regions of China (Qiu et al. 2017). Similar results were found for the origins of weedy rice in Thailand and Bhutan (Prathepha 2009; Ishikawa et al. 2005). Notably, crossing experiments involving intersub-specific and inter-varietal hybridization have generated progenies that exhibit weedy rice traits. Xiong 
a

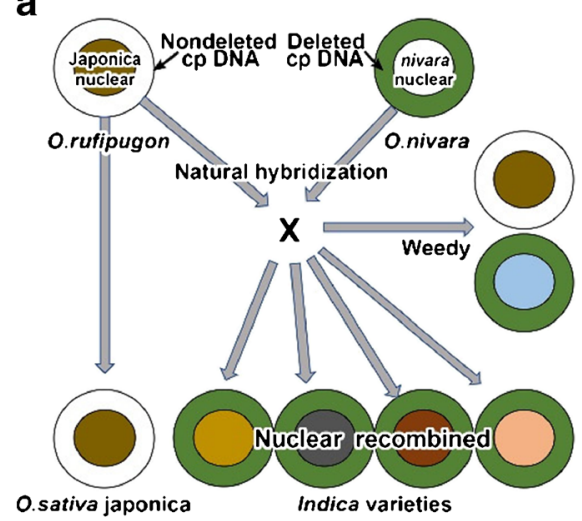

Fig. 2 Phylogenetic origin and evolution of weedy rice. a Phylogenetic origin of indica and japonica (varieties of Oryza sativa) and weedy rice, manifesting the hybridization and de-domesticated origination of weedy b

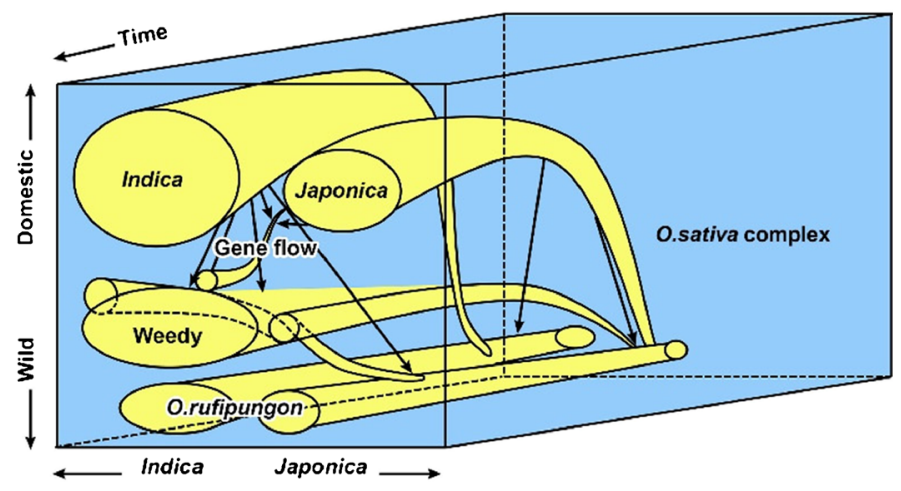

rice (Sato 2000). b Three-dimensional phylogenetic tree showing the relationships among wild, weedy, and cultivated strains of $O$. sativa (Sato 2000) et al. (2012) suggested that the occurrence of weedy rice among the progenies was higher in indica $\times$ japonica than indica $\times$ indica hybridizations.

\section{Distribution and genetic differentiation}

Weedy rice is widely distributed all around the globe (Fig. 3). The first reference to weedy rice in the literature was reported by Biroli in 1807 (Grimm 2014) and its occurrence in the USA was reported in 1898 (Chen and Suh 2015). In Korea, weedy rice was observed in 1916, where it was called "sharebyeo" by local farmers (Hara 1942). After 1960, the occurrence and infestation rate of weedy rice exploded around the globe due to the adoption of direct seeded rice culturing (Fogliatto et al. 2010). Weedy rice is genetically diverse (Chen 2001). Investigations based on different molecular markers have shown abundant polymorphism and indica-japonica differentiation in weedy rice (Cho et al. 1995; Suh et al. 1997; Estorninos et al. 2000; Bres-Patry et al. 2001; Federici et al. 2001; Cao et al. 2006; Zhang et al. 2006; Zhang et al. 2014; Chen and Suh 2015; Mao-bai et al. 2015). Chen (2001) reported the highest level of genetic diversity for SSR markers in weedy rice from Asia. Zhang et al. (2014) reported strong genetic differentiation for Asian weedy rice containing indica, japonica, and an intermediate type based on geographical distribution patterns. Studies have mentioned that indica weedy rice showed greater diversity in molecular markers and that it had a more complex genetic background than the japonica type weedy rice (Suh et al. 1997). Weedy rice from Northeast China has a very high genetic diversity, which is associated with several factors, such as weed management practices in a particular area, gene flow, and introgression among and between weedy rice and cultivars (Cao et al. 2006).

\section{Outcrossing and its associated concerns in weedy rice}

Although rice is a self-pollinating crop, variable levels of outcrossing have been detected (Chen et al. 2004). Interbreeding between cultivars and their weedy relatives takes place constantly, which produces viable and fertile hybrids with high vigor and dominant weedy traits (Langevin et al. 1990; Noldin et al. 2002). Gene flow from cultivars to weeds is feasible due to sexual compatibility and an overlap in flowering times between the two populations (Langevin et al. 1990). Environmental and other factors, such as the distance between two populations, temperature, relative humidity, flower morphology, and flowering time, also affect the rate of outcrossing (Chen et al. 2004; Shivrain et al. 2007, 2009). Introgression of foreign genes into the gene pool of weedy rice can enhance its genetic diversity and could confer some trait modifications that may or may not be of adaptive significance (Cao et al. 2006; Gealy et al. 2003; Prathepha 2009; Reagon et al. 2011; He et al. 2014; Goulart et al. 2012). Crop-to-weed gene flow is of special concern when transgenes are involved as it leads to the movement of genetically modified (GM) genes to weeds that might confer survival advantages that enable them to outcompete local strains (Oard et al. 2000; Lu and Snow 2005; Cao et al. 2006; Zhang et al. 2006; Yang et al. 2012). Crop-weed hybrids have been found to show variable levels of adaptability and survival capabilities (Burgos et al. 2008, 2014; Reagon et al. 2011; Song et al. 2011; Yang et al. 2012). Morphological 

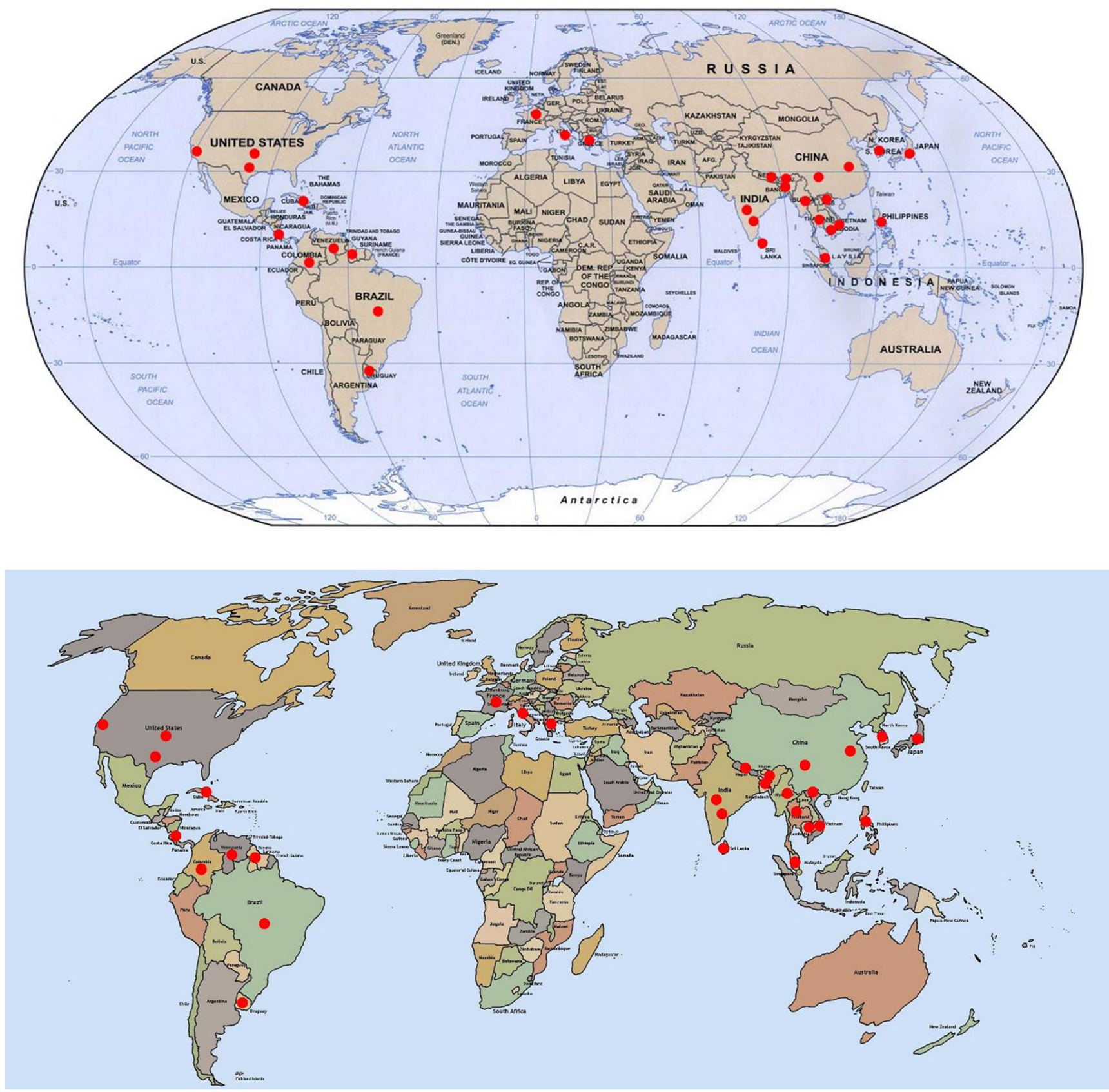

Fig. 3 Global distribution of weedy rice. The red circles denote the regions where weedy rice has been reported (Suh 2008; Chen and Suh 2015)

variations, such as short height and earlier flowering, are traits that have been suggested to be of adaptive significance to the weeds and allow them to escape eradication (Reagon et al. 2011). In contrast, reduced weediness in terms of reduced shattering can decrease the likelihood of weedy rice persistence (Burgos et al. 2014). Herbicide resistance genes could become common in weedy rice populations through continuous gene flow within 3 to 8 years of the initiation of herbicide-resistant rice production (Madsen et al. 2002). Longer-term accumulation of introgressed resistance alleles might result in the generation of more aggressive weedy populations that cannot be controlled easily. In such situations, the use of herbicides in herbicide-resistant varieties will have limited efficacy in controlling weedy rice infestations. In parallel to crop-to-weed gene flow, some gene flow also occurs in the reverse direction. This reverse flow of wild genetic material could result in the emergence of crop seeds that have incorporated dominant weedy rice traits (Burgos et al. 2008; Serrat et al. 2013). Ziska et al. (2012) found evidence to support the likelihood of increased weed crop gene flow with climate change and stated that climatic 
change has altered the phenological traits and enhanced the adaptive fitness value of weedy strains. As $\mathrm{CO}_{2}$ levels increased under experimental conditions, weedy rice responded strongly by producing more flowers and tillers and grew taller (Ziska et al. 2012). Therefore, changing climate is expected to alter the niche of weedy rice in rice communities.

\section{Adaptive evolutionary traits of weedy rice}

\subsection{Seed dormancy}

Seed dormancy is a state of temporary developmental arrest and is an adaptive trait used by plants including weedy rice. Weedy rice seeds show dormancies that range from a few days to years depending on the biotype and the storage conditions of the seeds after shattering (Vidotto and Ferrero 2000; Gianinetti and Cohn 2008; Veasey et al. 2004; Tseng et al. 2013). Weedy rice ecotypes lacking seed dormancy have also been reported (Xia et al. 2011). Different levels of interpopulation and intrapopulation variations have been reported for weedy rice seed dormancy (Gu et al. 2003, 2005; Fogliatto et al. 2012). Seed-covering-imposed and embryo-imposed dormancy has been identified in cultivated rice (Seshu and Sorrells 1986; Gu et al. 2003). However, only seedcovering-imposed dormancy has been reported in weedy rice ( $\mathrm{Gu}$ et al. 2003, 2005). About 10 epistatically interacting dormancy-related QTLs have been identified in weedy rice co-localized with genes for shattering, pericarp color, and flowering time (Cai and Morishima 2000; Thomson et al. 2003; Lee et al. 2005; Gu et al. 2003, 2004, 2005, 2011; Wen et al. 2008; Ye et al. 2010). Weedy rice seeds generally have increased seed longevity and remain viable for years compared to cultivated rice. Photoblastic weedy rice, whose germination is favored by light, was discovered among weedy rice collected from Korea (Chung and Paek 2003).

\subsection{Seed shattering}

Seed shattering is an undesirable agronomic trait in most cereal crops, especially in rice. Rice shows a wide variation in seed shattering. Early seed shattering is specific to wild and weedy rice (Oka 1988), and weedy rice grains disperse immediately by shattering at maturity. The persistence of weedy rice has been partly attributed to its ability to shatter seeds (Thurber et al. 2011) and it shows a wide variation in this seed shattering trait (Nunes et al. 2014). Rice seeds shatter subsequent to the development of an abscission layer between the grain and pedicel (Akasaka et al. 2011; Thurber et al. 2011; Yan et al. 2015). Shattering wild and weedy rice individuals possess well-defined abscission layers at flowering time, which are not present in domestic cultivars (Ferrero and
Vidotto 1998; Thurber et al. 2011; Akasaka et al. 2011). Four shattering genes, sh1, sh2, Sh3, and sh4, have been identified in rice (Subudhi et al. 2014). Lin et al. (2007) reported the involvement of a single dominant gene, Shattering 1 (SHA1), in seed shattering. Mutation in SHA1 results in reduced seed shattering by affecting abscission zone development (Li et al. 2006). Sequence comparisons of the mutation site of the gene revealed its presence in all the domesticated rice cultivars. Thurber et al. (2010) evaluated allelic identity and the diversity of shattering locus sh4 in US weedy rice. The haplotypes contained a single derived mutation at the $\operatorname{sh} 4$ locus. In another diversity study, the non-shattering sh4 allele was found to be present in all wild and weedy rice varieties with the heavy shattering phenotype (Zhu et al. 2012).

\subsection{Red pericarp color}

The most eye-catching characteristic of weedy rice is the red color of its pericarp. The red pericarp character is inherited from the ancestors of $O$. sativa and $O$. glaberrima that have red grains. The red pigmentation is a dominant character and is due to proanthocyanidin pigments (Wirjahardja et al. 1983). Red coloration to the pericarp is imparted by the combined action of $R c$ and $R d$ genes responsible for the accumulation of pigmentation in rice (Nagao et al. 1957; Sweeney et al. 2006; Furukawa et al. 2007). Weedy rice biotypes show variability in the pericarp color, and biotypes without red color are found (Prathepa 2009; Ziska et al. 2015). White pericarps develop from a mutation in the $R c$ gene, which results in the inhibition of flavonoid biosynthesis (Sweeney et al. 2007). Red pigmentation of the pericarp has adaptive significance and is associated with seed shattering and dormancy due to pleiotropic effects of the underlying $R c$-encoded bHLH transcription factor (Gu et al. 2003, 2011; Sweeney et al. 2007). Natural selection has probably favored the red pericarp color because of its association with seed dormancy, which increases the persistence of seeds in the soil seed bank.

\subsection{Stress tolerance}

Weedy rice shows pre-eminent adaptability to stressful environmental conditions (Suh 2003). Cold is one of the major abiotic stresses and rice varieties differ in their sensitivity to cold. Numerous studies have highlighted the superiority of weedy rice strains in tolerating cold stress when compared to cultivated rice (Kim 2007; Baek and Chung 2012, Chen and Suh 2015). Cold stress at the reproductive stage causes spikelet sterility and decreases grain yield (Yadav 2010). Another detrimental effect of cold stress is plasma membrane damage, which causes a loss of membrane integrity leading to lysis and solute leakage (Yadav 2010). Some weedy rice strains can maintain the integrity of their cells without any lysis under chilling conditions. This indicates that weedy rice cells are 
equipped with specialized mechanisms to combat the severe effects of low temperatures (Suh 2008). The exact mechanism underlying cold tolerance in weedy rice is unknown. Research has indicated that the cold tolerance potential of weedy rice is due to the combined action of various metabolites and antioxidant enzymes and the accumulation of antifreeze proteins in the cells (Kim 2007; Baek and Chung 2012; Wang et al. 2013). Besides cold tolerance, several weedy rice accessions with higher tolerances to drought and salinity stress have been identified (Chen and Suh 2015).

Burial depth and water depth are key factors that influence seedling vigor and crop yield. Rice cultivars do not usually emerge well from greater soil depths, whereas the weedy ecotypes can emerge from deeper soil profiles (Teekachunhatean 1985; Bevilacqua et al. 2015). Weedy rice seeds have been recorded to emerge from $13 \mathrm{~cm}$ of soil. However, delayed germination was observed when weedy rice seeds were buried at a soil depth of $20 \mathrm{~cm}$ (Vidotto and Ferrero 2000). Flooded soils are more anoxic compared to drained soils (Ponnamperuma 1972). Standing water favors rice growth by eliminating water stress, controlling weeds, and increasing the availability of nutrients (Ponnamperuma 1981). Weedy rice strains have a higher emergence ability at various water depths compared to wild and cultivated rice varieties (Suh 2008). The greater emergence ability of weedy rice may be attributed to its well-developed microtubules that promote mesocotyl elongation at the early seedling stage (Chung 2010).

Weedy rice generally possesses well-developed detoxification mechanisms that confer resistance to heavy metal stress. Increased root biomass, the development of adventitious roots, and upregulation of the synthesis of certain chelating agents by roots are generally involved in heavy metal tolerance mechanisms (Yang et al. 2000). Weedy rice was found to produce six times more root tips and three times more shoot biomass compared to cultivated rice when subjected to nitrogen deficiency (Burgos et al. 2006; Sales et al. 2011). A broadspectrum resistance to rice blast is another feature of weedy rice. Twenty-eight resistance QTLs have been discovered in US weedy rice ecotypes with some novel blast resistance $\mathrm{R}$ genes (Liu et al. 2015). Weedy rice resistance to blast is genotype dependent with indica type weedy rice having a higher resistance than japonica type weedy rice (Suh 2003). The Pita gene in rice has been effectively used to control rice blast disease (Bryan et al. 2000; Lee et al. 2009). US weedy rice shows lower genetic diversity at coding regions of the Pi-ta gene than other Oryza species (Lee et al. 2011). Lee et al. (2009) observed that all of the Pi-ta containing weedy types included an Ac family transposon insertion at the promoter region. It has been suggested that the susceptibility of some US weedy accessions to rice blast was due to a $2.2-\mathrm{Mb}$ introgressed block, which indicates that some additional genomic regions are also involved in $\mathrm{Pi}$-ta mediated resistance (Lee et al. 2009).

\section{Strategies to control and manage weedy rice}

It is very difficult to control weedy rice due to its peculiar morphology, crop mimicry, and resilience under severe environmental conditions. Appropriate management strategies are required to minimize yield loss and maintain constant rice production. To date, integrated control measures involving indirect and direct control methods have been implemented (Diarra et al. 1985; Azmi et al. 2000; Suh 2003; Vidotto and Ferrero 2000). Indirect control measures include the use of clean, weed-free seeds, tilling and land preparation, water management, choice of cultivar, and crop rotation. Direct control measures include manual weeding and chemical applications (Azmi et al. 2000). Planting high quality seeds that are free of weedy rice is an extremely important and a basic prevention measure for weedy rice control. All the machinery and equipment that are utilized in rice fields should be cleaned when moving from one field to another. Land preparation and manual weeding are typical methods for weedy rice control. Tilling the soil prior to crop planting should stimulate the emergence of weedy rice seedlings, which can then be destroyed by mechanical means, such as blade or rotary harrowing (Ferrero 2003). In contrast, row seeding or drill seeding rather than broadcasting the field with plants will help farmers to move between the rows to carry out manual weeding. The uniform and rapid seedling establishment ability of cultivated rice could provide an advantage against the strong competitive ability of weedy rice. Water management also effectively controls weedy rice populations. Flooding in well-leveled soils reduces weedy rice germination (Vidotto and Ferrero 2000). The alternative cultivation of direct seeding and transplanted method seems to be effective to decrease the weedy rice populations in rice fields (Suh et al. 1997; Cao et al. 2007). Rotations with other field crops, such as wheat, maize, soybean, sorghum, and mung beans, have also effectively controlled weedy rice (Watanabe et al. 1998). The most effective management of weedy rice is based on herbicide application to the field before and after the emergence of weedy rice but before rice-planting (Ferrero 2003). However, it does have some disadvantages. The anatomical and physiological similarity of weedy rice to cultivated rice makes it difficult to use post-emergence herbicides in rice fields, whereas antigerminative herbicide applications at the pre-emergence stage of weedy rice can be phytotoxic (Chen and Suh 2015). Another management strategy involves the use of herbicide-resistant rice varieties. There are two kinds of herbicide-resistant varieties. The non-genetically modified herbicide-resistant rice cultivars, such as the "Clearfield" rice system, have been introduced to many rice-growing parts of the USA, Europe, and Brazil. Since the adoption of Clearfield technology, weedy rice infestation has decreased in these areas. Up to $50 \%$ increases in rice production in Brazil due to Clearfield rice varieties have been reported (Merotto et al. 
2016). Significant increases in rice yield have been reported in Malaysia after Clearfield varieties were planted (Sudianto et al. 2013). However, the emergence of herbicide-resistant weedy rice with variable traits due to gene exchange between herbicide-resistant rice and weedy rice has become an obvious concern (Zhang et al. 2006; Burgos et al. 2014). In Arkansas, hybrids of weedy rice and Clearfield rice varieties growing in fields were found to be 10 to $60 \%$ herbicide-resistant (Burgos et al. 2014). These resistant varieties were found to have trait modifications in comparison to the historical weeds and cultivated varieties (Burgos et al. 2014). In Brazil, weedy rice hybrids with several trait modifications appeared in rice fields after 3 years of Clearfield rice cultivation, which substantially increased the cost of rice production in Brazil (Merotto et al. 2016). A study reported that the gene flow between Clearfield rice and weedy rice resulted in the generation of about 170 resistant plants per hectare (Shivrain et al. 2007). These advanced generations of herbicide-resistant weedy rice can easily escape eradication and ultimately evolve into selfpollinated plants (Suh 2008). A study revealed that the outcrossing frequency of the weedy rice grown in a Clearfield rice field showed a fourfold increase when studied in 2002-2003 (Zhang et al. 2006). Continuous cultivation of Clearfield rice is associated with the threat of transferring herbicide resistance to weedy rice from generation to generation. Therefore, to avoid the creation of such aggressive hybrids, strategies should be adopted that include not planting Clearfield rice for three consecutive growing seasons. Instead, rotating the planting of Clearfield rice over two consecutive growing seasons in the same field with another crop and the application of herbicides with a different mode of action can help reduce the aggressive weedy rice hybrids (Zhang et al. 2006).

Parallel to this, genetically modified (GM) herbicideresistant rice varieties have also been released on to the market under the trade name of "LibertyLink Rice," a technology developed by AgrEvo (a company that later became Aventis Crop Science). This GM rice has been approved in Australia, Brazil, the USA, Russia, Mexico, Canada, and Colombia; however, none of these approvals resulted in commercialization. In one study, the hybrids obtained after crossing weedy rice with glyphosate-resistant rice were more competitive and produced a larger number of seeds (Wang et al. 2013). Pollenmediated gene flow from GM herbicide-resistant rice to weedy rice expressed by the frequency of natural outcrossing varies depending on the combination of rice varieties and weedy rice strains and environmental factors, such as temperature, humidity, sunlight, and wind. However, under natural conditions, the outcrossing frequencies between GM herbicide-resistant rice cultivated in large areas and weedy rice populations might be more significant than the data observed in small-scale experiments (Chen et al. 2004). To minimize the pollen-mediated gene flow between GM rice and weedy rice, certain strategies can be adopted that include physical isolation of the transgenic crop, crop production rotation and molecular approaches to gene contamination (Suh 2003). The principles of molecular approaches for reducing gene flow are to alter gene flow by interfering with pollination and fertilization using maternal inheritance and male sterility, seed sterility, or reducing weed fitness acquired through introgression (also known as transgenic mitigation). However, the role of any technology in transgene containment needs to be scientifically justified (Lu 2003; Suh 2003).

A new weed management strategy is to use the allelopathic potential of plants. Batish et al. (2007) showed that the application of a dry powder of Tagetes minuta to rice fields suppressed weed emergence and increased crop yield. However, none of these methods are sufficient on their own. Any management strategy adopted should not only concentrate on reducing weed growth in the fields but should also focus on decreasing its persistence in the soil seed bank. As agriculture practices and climatic conditions change, weed management needs to be modified. The increasing infestation of weedy rice and economic losses means that we need to design new management strategies to cope with these problems. The development of new lines of Clearfield technology with superior herbicide resistance is under trial (Ziska et al. 2015). In addition, another herbicide-resistant rice system has been developed by the BASF Corporation where rice cultivars are resistant to ACCase-inhibiting herbicides. Cultivars with enhanced potential weed suppression, such as IR24, should be promoted. Biological control, including bio herbicides, may be an alternative to chemical herbicides in the future (Yamaguchi et al. 2000). Similarly, metagenomic approaches to the development of new herbicides using microorganisms for weed management may be suitable for future agriculture (Kao-Kniffin et al. 2013). We believe that an integrated approach, together with vigilance, knowledge, and effective management policies, can lead to the design of novel control strategies in rice cropping systems.

\section{Potential value of weedy rice}

Ralph Waldo Emerson wrote that "a weed is a plant whose virtues have not yet been discovered" and Vigueira et al. (2013) suggested that a weed's greatest virtue is its ability to adapt. Weedy rice has an extreme natural and versatile environmental adaptability. Weedy rice harbors various novel genes for resistance to biotic and abiotic stresses. Recent studies have suggested that weedy rice showed increased biomass production and high seed yields at elevated temperatures (Ziska et al. 2012). Increased seed yield at elevated temperatures is a trait that could be useful in developing new rice varieties that are more productive in an environment that will be altered by climate change (Ziska 
Fig. 4 Stress resistance and potential utilization of weedy rice. a Weedy rice strains showing tolerance to drought stress during vegetative stage. b Strong herbicide resistance potential of weedy rice. c Salinity tolerance potential of weedy rice strains (right 5) at seedling stage compared to cultivars (left 3 ) grown under high salinity condition $\mathrm{EC}=12 \mathrm{dSm}^{-1} \mathrm{NaCl}$ for 21 days. d Brown-colored rice varieties with high GABA content developed from japonica cultivar and a japonica weedy rice strain (right) compared to ordinary varieties (left) (Suh 2008; Chen and Suh 2015)

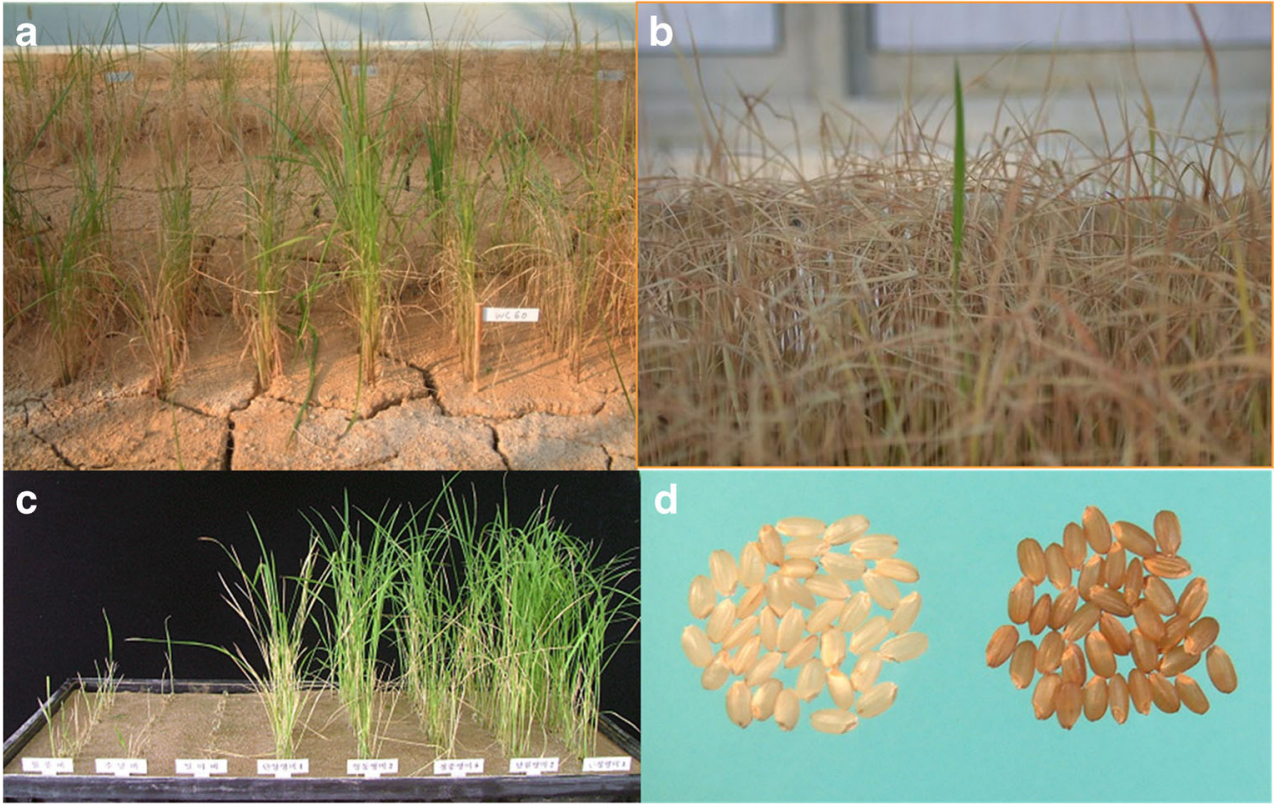

et al. 2012). Furthermore, weedy rice has shown higher tolerance to drought, cold, salinity, rice blast, and bacterial blight disease (Suh 2003). Higher levels of stress tolerance could potentially make it an ideal candidate to screen for specific genes and their introgression in cultivated varieties, particularly for enhanced stress tolerance (Fig. 4). A rice variety tolerant to drought and coldness, Cheonsu, was developed from an Ilmibyeo//Juanbyeo/Salshare cross, where the parents, Ilmibyeo and Juanbye, are japonica cultivars, and Salshare is a japonica weedy rice from Korea (Suh 2008).

Recently, some studies have reported the gene flow from GM herbicide-resistant rice varieties to weedy rice and its evolutionary consequences (Oard et al. 2000; Messeguer et al. 2001, 2004; Chen et al. 2004; Wang et al. 2013). These studies have mentioned that this gene flow has diversified the genotype and phenotype of weedy rice populations growing along with GM varieties in the fields. Weedy rice populations growing among GM varieties in the rice fields could be used for the biosafety assessment of transgene, i.e. herbicide-resistant gene, flow, and its overall consequences on other wild and weedy flora. So far, only one GM herbicide-resistant rice variety has been released onto the market. The dataset on gene flow between GM herbicide-resistant rice and weedy rice will be important in the future and could be consulted before the release of any other transgenic variety onto the market. As already mentioned, the gene flow between resistant rice varieties and weedy rice has generated hybrid weedy rice populations with variable traits. Herbicide-resistant weedy rice grown in rice fields were found to have short heights, early flowering, and reduced seed shattering (Burgos et al.
Fig. 5 Framework for the sustainable management and utilization of weedy rice. This framework covers study and utilization of weedy rice in different aspects at morphological, genetic, and agroecological levels

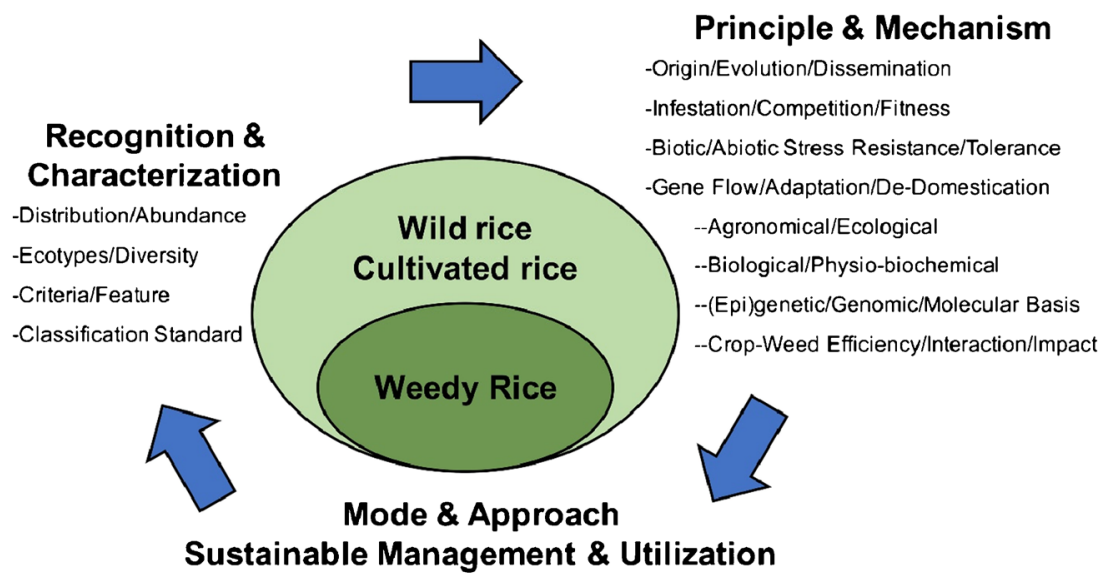

-Integrated Control Procedures/Strategies/Policies

-Utilization Approaches/Conventional Technique and Biotechnology 
2008, 2014; Reagon et al. 2011; Song et al. 2011; Yang et al. 2012). Furthermore, the insect-resistant weedy rice hybrids generated from crossing weedy rice with insectresistant cultivated varieties have also led to increased seed production (Wang et al. 2011). Therefore, we suggest that these modified generations of weedy rice should be explored for these trait modifications. It can help in understanding the biology of these traits at the molecular level. Furthermore, these hybrid weedy genes may be exploited for novel genes that can be used for breeding improved cultivars (Wang et al. 2011; Engku et al. 2016). Weedy rice grains show high chemical component diversity, including amylose, gamma aminobutyric acid (GABA), and protein contents (Suh 2008; Chen and Suh 2015). In Korea, a japonica rice variety with a high amylose content (27\%), Goami, was developed from the progeny of a Milyang 95// Gimcheonaengmi/Ilpumbyeo ${ }^{* 2}$ cross. The brown-colored rice varieties with high levels of GABA, which is related to brain activity, Geumtap and Noreunjachal, were developed from a cross between a japonica cultivar and a japonica weedy rice strain. The red pericarp color is imparted by the pigment proanthocyanidin, which possesses strong antioxidant activity. These characteristics of weedy rice could lead to the breeding of rice with enhanced nutritional qualities and weedy rice has been used previously to breed japonica type hybrid rice (Tan et al. 2011).

Weedy rice has been reported to differentiate and survive in a particular habitat for many years (Chen and Suh 2015). Furthermore, weedy rice shares intermediate characteristics between wild and cultivated rice (Chen 2001), which make it an excellent model for genetic studies on evolution. Domestic rice has evolved through various genetic adaptations introduced under human selection. These adaptations have led to remarkable changes in the overall physiology, morphology, and genetics of rice. Identifying the genetic variations associated with a particular trait of weedy rice can provide new insights into rice domestication. Furthermore, weedy rice can also be considered to be a model (weedy crop relative) for evolutionary and molecular studies of traits, such as shattering, dormancy, and a red pericarp. A framework for the sustainable management and utilization of weedy rice is proposed in Fig. 5.

\section{Future outlook}

Contemporary agriculture has never been more complex. The changing climate, limited availability and access to resources, and challenges and constraints in rice production require informed decisions and strategies to achieve sustainable rice production. There is a need to design and implement modern and cost-effective management strategies. New management strategies using agro-biotechnology together with traditional practices may offer markedly improved weed control strategies. However, any mitigation tactic to control weedy rice infestation is not individually guaranteed and an integrated approach based on a combination of general and technological tactics could be helpful in the effective management of weedy rice.

Rice genetic backgrounds are becoming narrower, but mixing them with foreign germplasm can increase genetic diversity. Wild germplasm contains many genes that are capable of improving cultivars in terms of quality and yield. However, the incorporation of genes from wild species that are distantly related to $O$. sativa requires more sophisticated approaches than conventional breeding. Furthermore, reproduction barriers, such as low crossing ability and hybrid non-viability, limit the gene transfer between cultivated rice and wild rice. In addition, the introgression of genes from wild relatives could be detrimental if they are linked to negative traits, such as reduced yield. Therefore, the use of wild germplasm requires a detailed physiological analysis of the segregating generations, which is tedious and time consuming. Due to close genetic relationships and longtime sympatric distribution, weedy rice can serve as an alternative for improving cultivated rice. Uncovering the genetic basis of the various physiological, morphological, and developmental traits of weedy rice can help identify the favorable trait-related genes in weedy germplasm. With tools such as genome wide association studies (GWAS) and re-sequencing approaches, we can dissect the genetic architecture of various desired traits in weedy accessions, such as high stress tolerance, disease resistance, and greater biomass production ( $\mathrm{Li}$ et al. 2017; Qiu et al. 2017). A GWAS of the agronomic traits of weedy rice can allow these weedy genes to be used in traditional programs for breeding more competitive cultivars with improved quality and yield.

The development of new multiple herbicide-resistant rice varieties should be emphasized. Furthermore, crop rotation with other transgenic crops, e.g., glyphosate resistant maize, has considerably controlled weedy rice problems in the Philippines (Chauhan 2013). Searching for new broadspectrum herbicides that can be applied at the postemergence stage will also help in controlling weedy rice infestations. Exploring soil microbes for secondary metabolites that have seed deterioration and growth inhibition potential should be emphasized for weedy rice management. Weedy rice hybrids with variable traits that appeared as a result of gene flow may be considered valuable for evolutionary, biological, and breeding studies. Variations in traits at the molecular level could be used to design new management strategies to control future, advanced weedy rice generations. Information about the geographic distribution, population ecology, and reproductive biology of weedy rice could be used to evaluate the ecological effects of new transgenic traits. 


\section{Conclusion}

It is especially important for domestic rice to incorporate tolerance to the extreme climatic conditions that may arise over the coming decades in terms of constrained water supply and rising temperatures. Improvement of rice through biotechnology is an increasingly urgent priority. Initial approaches involve targeted transfer of genes from $O$. sativa landraces and wild germplasm into $O$. sativa through conventional breeding programs. There are some disadvantages to the incorporation of genes from wild species into cultivated rice, such as incompatible crosses and linkage drag. Nevertheless, other Oryza species must be explored for favorable traits and stably introgressed into O. sativa. Despite the disadvantages of using weedy rice, rice breeders might in the future be able to use its traits to develop commercial rice cultivars that have better tolerance to various biotic and abiotic stresses, along with enhanced agronomic features.

Acknowledgements This study was supported by a grant from Ministry of Science and Technology of China (grant No. 2016YFD0101101-5), grant from National Natural Science Foundation of China (grant No. 31360257 and 31650410651), and TWAS fellowship for research and advanced training.

Open Access This article is distributed under the terms of the Creative Commons Attribution 4.0 International License (http:// creativecommons.org/licenses/by/4.0/), which permits unrestricted use, distribution, and reproduction in any medium, provided you give appropriate credit to the original author(s) and the source, provide a link to the Creative Commons license, and indicate if changes were made.

\section{References}

Aggarval RK, Brar DS, Klush GS (1997) Two new genomes in the Oryza complex identified on the basis of molecular divergence analysis, using total genomic DNA hybridization. Mol Gen Genet 254:1. https://doi.org/10.1007/s004380050384

Akasaka M, Konishi S, Izawa T, Ushiki J (2011) Histological and genetic characteristics associated with the seed-shattering habit of weedy rice (Oryza sativa L.) from Okayama, Japan. Breed Sci 61:168173. https://doi.org/10.1270/jsbbs.61.168

Ali A, Erenstein O, Rahut DB (2014) Impact of direct rice sowing technology on rice producers' earnings: empirical evidence from Pakistan. Development Studies Research 1(1):244-254. https://doi. org/10.1080/21665095.2014.943777

Arashi K (1974) Consideration on red rice in Japan. Yuankaku, Tokyo, p 295

Arrieta-Espinoza G, Sanchez E, Vargas S, Lobo J, Quesada T, Espinoza AM (2005) The weedy rice complex in Costa Rica. I. Morphological study of relationships between commercial rice varieties, wild Oryza relatives and weedy types. Genet Resour Crop Evol 52:575-587. https://doi.org/10.1007/s10722-004-6109-x

Azmi M, Abdullah MZ, Mislamah B, Baki BB (2000) Management of weedy rice (Oryza sativa L): the Malaysian experience. In: Baki BB, Chin DV, Mortimer M (eds) Wild and weedy rice in rice ecosystems in Asia: a review. IRRI Press, Los Banos
Baek JS, Chung NJ (2012) Seed wintering and deterioration characteristics between weedy and cultivated rice. Rice 5:21. https://doi.org/10. 1186/1939-8433-5-21

Batish DR, Arora K, Singh HP, Kohli RK (2007) Potential utilization of dried powder of Tagetes minuta as a natural herbicide for managing rice weeds. Crop Prot 26:566-571. https://doi.org/10.1016/j.cropro. 2006.05.008

Bevilacqua CB, Basu S, Pereira A, Tseng TM, Zimmer PD, Burgos NR (2015) Analysis of stress-responsive gene expression in cultivated and weedy rice differing in cold stress tolerance. PLoS One 10(7): e0132100. https://doi.org/10.1371/journal.pone.0132100

Bhatia CR, Mitra R (2003) Consequences of gene flow from genetically engineered crops. Curr Sci 84(2)

Bres-Patry C, Lorieu M, Clement G, Bangratz M, Ghesquiere A (2001) Heredity and genetic mapping of domestication-related traits in a temperate japonica weedy rice. Theor Appl Genet 102:118-126. https://doi.org/10.1007/s001220051626

Bryan GT, Wu KS, Farrall L, Jia Y, Hershey HP (2000) A single aminoacid difference distinguishes resistant and susceptible alleles of the rice blast resistance gene $\mathrm{Pi}$-ta. Plant Cell 12:2033-2045. https://doi. org $/ 10.1105 / \mathrm{tpc} .12 .11 .2033$

Burgos NR, Norman RJ, Gealy DR, Black H (2006) Comparative N uptake between rice and weedy rice. Field Crop Res 99(2-3):96105. https://doi.org/10.1016/j.fcr.2006.03.009

Burgos NR, Norsworthy JK, Scott RC, Smith KL (2008) Red rice status after five years of ClearfieldTM rice technology in Arkansas. Weed Technol 22:200-208. https://doi.org/10.1002/ps.1802

Burgos NR, Norman RJ, Singh V, Tseng TM, Black H, Young ND, Huang Z, Hyma KE, Gealy DR, Caiced AL (2014) The impact of herbicide-resistant rice technology on phenotypic diversity and population structure of United States weedy rice. Plant Physiol 166: 1208-1220. https://doi.org/10.1104/pp.114.242719

Cai HW, Morishima H (2000) Genomic regions affecting seed shattering and seed dormancy in rice. Theor Appl Genet 100:840-846. https:// doi.org/10.1007/s001220051360

Cao Q, Lu BR, Xia H, Rong J, Sala F, Spada A, Grassi F (2006) Genetic diversity and origin of weedy rice (Oryza sativa f. spontanea) populations found in northeastern China revealed by simple sequence repeat markers. Ann Bot 98:1241-1252. https://doi.org/10.1093/ $\mathrm{aob} / \mathrm{mcl} 210$

Cao QJ, Li B, Song ZP, Cai XX, Lu BR (2007) Impact of weedy rice populations on the growth and yield of direct-seeded and transplanted rice. Weed Biol Manag 7:97-104. https://doi.org/10. 1111/j.1445-6664.2007.00241.x

Carney J (2004) With grains in her hair: rice in colonial Brazil. Slavery and Abolition 25(1):1-27

Catala M, Eleftherohorinos I, Martins L, Vidotto F, Ferrero A, Dhima K, Feougier G, Mouret J (2002) Red rice control in Southern Europe with pre-and postemergence applied herbicides

Chauhan BS (2013) Strategies to manage weedy rice in Asia. Crop Prot 48:51-56. https://doi.org/10.1016/j.cropro.2013.02.015

Chen LJ (2001) Genetic diversity and phylogenetic relationships among cultivated, weedy and wild rice. Thesis for Ph.D. in Yeungnam University, Korea

Chen LJ, Suh HS (2015) Weedy rice - origin and dissemination. Yunnan Publishing Group Corporation, Yunnan Science and Technology Press, China. pp 234

Chen LJ, Lee DS, Song ZP, Suh HS, Lu BR (2004) Gene flow from cultivated rice (Oryza sativa) to its weedy and wild relatives. Ann Bot 93:1-7. https://doi.org/10.1093/aob/mch006

Cho YC, Chung TY, Suh HS (1995) Genetic characteristics of Korean weedy rice (Oryza sativa L.) by RFLP analysis. Euphytica 86:103110. https://doi.org/10.1007/BF00022015

Chung NJ (2010) Elongation habit of mesocotyls and coleoptiles in weedy rice with high emergence ability in direct-seeding on dry 
paddy fields. Crop Pasture Sci 61:911-917. https://doi.org/10.1071/ CP10099

Chung NJ, Paek NC (2003) Photoblastism and ecophysiology of seed germination in weedy rice. Agron J 95:184-190. https://doi.org/ 10.2134/agronj2003.1840

De-Wet JMJ, Harlan JR (1975) Weeds and domesticates: evolution in the man-made habitat. Econ Bot 29:99. https://doi.org/10.1007/ BF02863309

Diallo S (1999) Problème posé par le riz rouge en riziculture au Sénégal. Global Workshop on Red Rice Control. In: FAO Plant Production and Protection Division (Rome, Italy)

Diarra ARJ, Smith RJ, Talbert RE (1985) Red rice (Oryza sativa) control in drill-seeded rice (O. sativa). Weed Sci 33:703-707

Ellstrand NC, Heredia SM, Leak-Garcia JA, Heraty JM, Burger JC, Yao L, Nohzadeh-Malakshah S, Ridley CE (2010) Crops gone wild: evolution of weeds and invasive from domesticated ancestors. Evol Appl 3:494-504. https://doi.org/10.1111/j.1752-4571.2010. 00140.x

Engku AK, Norida1 M, Juraimi AS, Rafii MY, Abdullah SNA, Alam MA (2016) Gene flow from Clearfield $®$ rice to weedy rice under field conditions. Plant Soil Environ 62(1):16-22. https://doi.org/10. 17221/616/2015-PSE

Estorninos LE Jr, Gealy DR, Talbert RE (2000) Interference between red rice and rice in a replacement series studies. Weed Technol 16(2): 401-106. https://doi.org/10.1614/0890-037X(2002)016[0401: GROROS]2.0.CO;2

Federici MT, Vaughan D, Tomooka N, Kaga A, Wang XW, Doi K, Francis M, Zorrilla G, Saldain N (2001) Analysis of Uruguayan weedy rice genetic diversity using AFLP molecular markers. EJB (available at http://www.ejb.org/content/vol4/issue3/full/3

Ferrero A (2003) Weedy rice, biological features and control. FAO Plant Production and Protection Paper (FAO)

Ferrero A, Vidotto F (1998) Germinability after flowering, shattering ability and longevity of red rice seeds. 6th EWRS Mediterranean Sym. 1998, Montpellier, 205-2011

Fogliatto S, Vidotto F, Ferrero A (2010) Effects of winter flooding on weedy rice (Oryza sativa L.) Crop Prot 29:1232-1240. https://doi. org/10.1016/j.cropro.2010.07.007

Fogliatto S, Vidotto F, Ferrero A (2012) Morphological characterisation of Italian weedy rice (Oryza Sativa) populations. Weed Res 52:60 69. https://doi.org/10.1111/j.1365-3180.2011.00890.x

Furukawa T, Maekawa M, Oki T, Suda T, Iida S, Shimada H, Takamure I, Kadowaki K (2007) The $R c$ and $R d$ genes are involved in proanthocyanidin synthesis in rice pericarp. Plant J 49:91-102. https://doi.org/10.1111/j.1365-313X.2006.02958.x

Gealy DR (2005) Gene movement between rice (Oryza sativa) and weedy rice (Oryza sativa) - a U.S. temperate rice perspective. In: Gressel J (ed) Crop ferality and volunteerism. CRC Press, Boca Raton, pp 323-354

Gealy DR, Mitten DH, Rutger JN (2003) Gene flow between red rice (Oryza sativa) and herbicide resistant rice (O. sativa): implications for weed management 1 . Weed Technol 17(3):627-645. https://doi. org/10.1614/WT02-100

Gianinetti A, Cohn MA (2008) Seed dormancy in red rice XIII. Interaction of dry after ripening and hydration temperature. Seed Sci Res 18:151-159. https://doi.org/10.1017/S0960258508037999

Goulart ICGR, Pacheco MT, Nunes AL, Merotto A (2012) Identification of origin and analysis of population structure of field-selected imidazolinone-herbicide resistant red rice (Oryza sativa). Euphytica 187:437-447. https://doi.org/10. 1007/s10681-012-0738-5

Grimm A (2014) Characterization of weedy rice groups in Northern Italy and investigation of their evolutionary origins. $\mathrm{PhD}$ Thesis, Karlsruher Institut für Technologie (KIT) - Universitätsbereich genehmigte
Gu XY, Chen ZX, Foley ME (2003) Inheritance of seed dormancy in weedy rice. Crop Sci 43:835-843. https://doi.org/10.2135/ cropsci2003.8350

Gu XY, Kianian SF, Foley ME (2004) Multiple loci and epistases control genetic variation for seed dormancy in weedy rice (Oryza sativa). Genetics 166:1503-1516. https://doi.org/10.1534/genetics.166.3. 1503

Gu XY, Kianian SF, Foley ME (2005) Dormancy imposed by covering tissues interrelated with seed shattering and morphological characteristics in weedy rice (Oryza sativa.) Crop Sci 45:948-955. https:// doi.org/10.2135/cropsci2004.0339

Gu XY, Foley ME, Horvath DP, Anderson JV, Feng J, Zhang L et al (2011) Association between seed dormancy and pericarp color is controlled by a pleiotropic gene that regulates abscisic acid and flavonoid synthesis in weedy red rice. Genetics 89(4):1515-1524. https://doi.org/10.1534/genetics.111.131169

Hara S (1942) Persistence of an Indica rice in Korea. Nogyo Oyobi Engei (Agriculture and Horticulture) 17:705-712

He Z, Jiang X, Ratnasekera D, Grassi F, Perera U (2014) Seed-mediated gene flow promotes genetic diversity of weedy rice within populations: implications for weed management. PLoS One 9(12): e112778. https://doi.org/10.1371/journal.pone.0112778

Holm LR, Doll J, Holm E, Pancho J, Herberger J (1979) The wild rices. Oryza sativa L., Oryza punctata Kotschy ex Steud., Oryza rufipogon Griff., Oryza barthii A. Chev. (syn. O. breviligulata A. Chev. Et Roehr) and Oryza officinalis Wall ex Watt. In: World weeds. Natural histories and distribution. John Wiley and Sons, Inc, New York, pp 531-547

Ishikawa R, Toki N, Imai K, Sato YI, Yamagishi H, Shinamoto Y (2005) Origin of weedy rice grown in Bhutan and the force of genetic diversity. Genet Resour Crop Evol 52:395-403. https://doi.org/10. 1007/s10722-005-2257-x

Kao-Kniffin J, Carver SM, DiTommaso A (2013) Advancing weed management strategies using metagenomic techniques. Weed Sci 61(2): 171-184. https://doi.org/10.1614/WS-D-12-00114.1

Kim SS (2007) Identification of cold tolerance genes expressed in weedy rice. Thesis for Ph.D. in Yeungnam University, Korea

Langevin SA, Clay K, Grace JB (1990) The incidence and effects of hybridization between cultivated rice and its related weed red rice (O. sativa L.) Evolution 44:1000-1008. https://doi.org/10.2307/ 2409561

Lee SJ, Oh CS, Suh JP, McCouch SR, Ahn SN (2005) Identification of QTLs for domestication-related and agronomic traits in an Oryza sativa $\times$ O. rufipogon BC1F7 population. Plant Breed 124:209 219. https://doi.org/10.1111/j.1439-0523.2005.01092.x

Lee S, Costanzo S, Jia Y, Olsen KM, Caicedo AL (2009) Evolutionary dynamics of the genomic region around the blast resistance gene $\mathrm{Pi}$ ta in AA genome Oryza species genetics 183: 1315-1325. doi: https://doi.org/10.1534/genetics.109.108266

Lee S, Jia Y, Jia M, Gealy DR, Olsen KM (2011) Molecular evolution of the rice blast resistance gene Pi-ta in invasive weedy rice in the USA. PLoS One 6(10):e26260. https://doi.org/10.1371/journal. pone. 0026260

Li C, Zhou A, Sang T (2006) Rice domestication by reducing shattering. Science 311(5769):1936-1939. https://doi.org/10.1126/science. 1123604

Li LF, Li YL, Jia Y, Caicedo AL, Olsen KM (2017) Signatures of adaptation in the weedy rice genome. Nature Genet 49:811-814. https:// doi.org/10.1038/ng.3825

Lin Z, Griffith ME, Li X, Zhu Z, Tan L, Fu Y, Zhang W, Wang X, Xie D, Sun C (2007) Origin of seed shattering in rice (Oryza sativa L.) Planta 226(1):11-20. https://doi.org/10.1007/s00425-006-0460-4

Liu Y, Qi X, Gealy DR, Olsen KM, Caicedo AL, Jia Y (2015) QTL analysis for resistance to blast disease in US weedy rice. Mol Plant-Microbe Interact 28(7):834-844. https://doi.org/10.1094/ MPMI-12-14-0386-R 
Londo JP, Schaal BA (2007) Origins and population genetics of weedy red rice in the USA. Mol Ecol 16:4523-4535. https://doi.org/10. 1111/j.1365-294X.2007.03489.x

Lu BR, Snow AA (2005) Gene flow from genetically modified rice and its environmental consequences. Bioscience 55(8):669-678. https:// doi.org/10.1641/0006-3568(2005)055[0669:GFFGMR]2.0.CO;2

Lu BR, Yang X, Ellstrand NC (2016) Fitness correlates of crop transgene flow into weedy populations: a case study of weedy rice in China and other examples. Evol Appl 9:857-870. https://doi.org/10.1111/ eva. 12377

Madsen KH, Valverde BE, Jensen JE (2002) Risk assessment of herbicide resistant crops: a Latin American perspective using rice (Oryza sativa) as a model. Weed Technol 16:215-223. https://doi.org/10. 1614/0890-037X(2002)016[0215:RAOHRC]2.0.CO;2

Mao-bai L, Wang H, Li-ming C (2015) Evaluation of population structure, genetic diversity and origin of northeast Asia weedy rice based on simple sequence repeat markers. Rice Sci 22(4):180-188. https:// doi.org/10.1016/j.rsci.2015.02.001

Merotto A Jr, Goulart ICGR, Nunes AL, Kalsing A, Markus C, Menezes VG, Wander AE (2016) Evolutionary and social consequences of introgression of nontransgenic herbicide resistance from rice to weedy rice in Brazil. Evol Appl 9(7):837-846

Messeguer J, Fogher C, Guiderdoni E, Marfa V, Catala MM, Baldi G, Mele E (2001) Field assessments of gene flow from transgenic to cultivated rice (Oryza sativa L.) using a herbicide resistance gene as tracer marker. Theor Appl Genet 103:1151-1159. https://doi.org/10. 1007/s001220100713

Messeguer J, Marfa V, Catala MM, Guiderdoni E, Mele E (2004) A field study of pollen-mediated gene flow from Mediterranean GM rice to conventional rice and the red rice weed. Molecular Breed 13:103112

Nagao S, Takahashi M, Miyamoto T (1957) Genetic studies on rice plant, XXI. Biochemical studies on red rice pigmentation. Jpn J Genet 32: 124-128. https://doi.org/10.1266/jjg.32.124

Noldin JA, Yokoyama S, Antunes P, Luzzardi R (2002) Outcrossing potential of glufosinate-resistant rice to red rice. Planta Daninha 20:243-251. https://doi.org/10.1590/S0100-83582002000200011

Nunes AL, Delatorre CA, Merotto A (2014) Gene expression related to seed shattering and the cell wall in cultivated and weedy rice. Plant Biol J 16:888-896. https://doi.org/10.1111/plb.12133

Oard J, Cohn MA, Linscombe S, Gealy D, Gravois K (2000) Field evaluation of seed production, shattering and dormancy in hybrid populations of transgenic rice (Oryza sativa) and the weed, red rice (Oryza sativa). Plant Sci 155:13-22. https://doi.org/10.1016/ S0168-9452(00)00245-4

Oka HI (1988) Origin of cultivated rice. Japan Science Society Press, Tokyo

Olofsdotter M, Valverde BE, Madsen KH (2000) Herbicide resistant rice (Oryza sativa L.): global implications for weedy rice and weed management. Ann Appl Biol 137(3):279-295

Ponnamperuma FN (1972) The chemistry of submerged soils. Adv Agron 24:29-96. https://doi.org/10.1016/S0065-2113(08)60633-1

Ponnamperuma FN (1981) Properties of tropical rice soils. Lecture series delivered to graduate students at the Tropical Agriculture College, H. Cardenas, Tabasco, Mexico, July 23-25, 1981

Prathepha P (2009) Seed morphological traits and genotypic diversity of weedy rice (Oryza sativa f. spontanea) populations found in the Thai Hom Mali rice fields of north-eastern Thailand. Weed Biol Manag 9:1-9. https://doi.org/10.1111/j.1445-6664.2008.00312.x

Qiu J, Zhu J, Fu F, Ye CY, Wang W, Mao L, Qiang S, Liu TL, Fan LJ (2014) Genome re-sequencing suggested a weedy rice origin from domesticated indica-japonica hybridization: a case study from southern China. Planta 240:1353-1363. https://doi.org/10.1007/ s00425-014-2159-2

Qiu J, Zhou YJ, Mao LF, Ye CY, Wang WD, Zhang JP, Yu YY, Fu F, Wang YF, Qian FJ, Qi T, Wu SL, Sultana MH, Cao Y-N, Wang Y,
Timko MP, Ge S, Fan LJ, Lu YL (2017) Genomic variation associated with local adaptation of weedy rice during de-domestication. Nature Comm 8:1-12. https://doi.org/10.1038//ncomms15323

Rao AN, Johnson DE, Sivaprasad B, Ladha JK, Mortimer AM (2007) Weed management in direct-seeded rice. Adv Agron 93:153-255. https://doi.org/10.1016/S0065-2113(06)93004-1

Rathore M, Singh R, Kumar B, Chauhan BS (2016) Characterization of functional trait diversity among Indian cultivated and weedy rice populations. Sci Rep 6:24176. https://doi.org/10.1038/srep24176

Reagon M, Thurber CS, Olsen KM, Jia Y, Caicedo AL (2011) The long and short of it: SD1 polymorphism and the evolution of growth trait divergence in U.S. weedy rice. Mol Ecol 20:3743-3756. https://doi. org/10.1111/j.1365-294X.2011.05216.x

Rodenburg J, Meinke H, Johnson DE (2010) Challenges for weed management in African rice systems in a changing climate. J Agr Sci 149:427-435. https://doi.org/10.1017/S0021859611000207

Sales MA, Burgos NR, Shivrain VK, Murphy B, Gbur EE Jr (2011) Morphological and physiological responses of weedy red rice (Oryza sativa L.) and cultivated rice (O. sativa) to N supply. AJPS 2:569-577. https://doi.org/10.4236/ajps.2011.24068

Sato YI (2000) Origin and evolution of wild, weedy and cultivated rice. Wild and weedy rice in rice ecosystems in Asia-review, IRRI

Serrat X, Esteban R, Peñas G, Català MM, Melé E, Messeguer J (2013) Direct and reverse pollen-mediated gene flow between GM rice and red rice weed. AoB Plants 5:1-12. https://doi.org/10.1093/aobpla/ plt050

Seshu DV, Sorrells ME (1986) Genetic studies on seed dormancy in rice. In: Rice genetics. IRRI, Manila. p. 369-382

Shivrain VK, Burgos NR, Anders MM, Rajguru SN, Moore JW, Sales MA (2007) Gene flow between clearfield rice and red rice. Crop Prot 26:349-356. https://doi.org/10.1016/j.cropro.2005.09.019

Shivrain VK, Burgos NR, Gealy DR, Smith KL, Scott RC, Mauromoustakos A, Black H (2009) Red rice (Oryza sativa) emergence characteristics and influence on rice yield at different planting dates. Weed Sci 57:94-102. https://doi.org/10.1614/WS-09-003.1

Singh KK, Lohan SK, Jat AS, Rani T (2006) New technologies of planting rice for higher production. Res on Crops 7:369-371

Smith RJ Jr (1981) Control of red rice (Oryza sativa L.) in water seeded rice (Oryza sativa L.) Weed Sci 29:61-62 http://www.jstor.org/ stable/4043473

Song X, Wang Z, Qiang S (2011) Agronomic performance of F1, F2 and F3 hybrids between weedy rice and transgenic glufosinate-resistant rice. Pest Manag Sci 67:921-931. https://doi.org/10.1002/ps.2132

Subudhi PK, Singh PK, DeLeon T, Parco A, Karan R, Biradar H, Cohn MA, Sasaki T (2014) Mapping of seed shattering loci provides insights into origin of weedy rice and rice domestication. J Hered 105(2):276-287. https://doi.org/10.1093/jhered/est089

Sudianto E, Song BK, Neik TX, Saldain NE, Scott RC, Burgos NR (2013) Clearfield ${ }^{\circledR}$ rice: its development, success, and key challenges on a global perspective. Crop Pro 49:40-51

Suh HS (2003) Characterization of weedy rice germplasm. Wild Crop Germplasm Bank, Yeungnam University, pp 1007

Suh HS (2008) Weedy rice. Wild Crop Germplasm Bank, Yeungnam University, pp 240

Suh HS, Sato YI, Morishima H (1997) Genetic characterization of weedy rice (Oryza sativa L.) based on morpho-physiology isozymes and RAPD markers. Theor Appl Genet 94:316-321. https://doi.org/10. 1007/s001220050417

Sun J, Qian Q, Ma DR, Xu ZJ, Liu D, Du HB, Chen WF (2013) Introgression and selection shaping the genome and adaptive loci of weedy rice in northern China. New Phytol 197:290-299. https:// doi.org/10.1111/nph.12012

Sweeney MT, Thomson MJ, Pfeil BE, McCouch S (2006) Caught redhanded: Rc encodes a basic helix-loop-helix protein conditioning red pericarp in rice. Plant Cell 18:283-294. https://doi.org/10. $1105 /$ tpc. 105.038430 
Sweeney MT, Thomson MJ, Cho YG, Park YJ, Williamson SH, Bustamant CD, McCouchet SR (2007) Global dissemination of a single mutation conferring white pericarp in rice. PLoS Genet 3(8): 1418-1424. https://doi.org/10.1371/journal.pgen.0030133

Tan L, Rong DM, Xua ZJ, Deng HF, Chena WF, Yuan LP (2011) Utilization of weedy rice for development of japonica hybrid rice (Oryza sativa L.) Plant Sci 180:733-740. https://doi.org/10.1016/j. plantsci.2011.02.002

Tang LH, Morishima H (1997) Genetic characterization of weedy rices and the inference on their origins. Jpn J Breed 47:153-160. https:// doi.org/10.1270/jsbbs1951.47.153

Teekachunhatean T (1985) Release, induction and significance of dormancy in seeds of red rice (Oryza sativa L.). Ph.D. dissertation. Mississippi State University, USA

Thomson MJ, Tai TH, McClung AM, Lai XH, Hinga ME, Lobos KB, Xu Y, Martinez CP, McCouch SR (2003) Mapping quantitative trait loci for yield, yield components and morphological traits in an advanced backcross population between Oryza rufipogon and the Oryza sativa cultivar Jefferson. Theor Appl Genet 107:479-493. https://doi.org/ 10.1007/s00122-003-1270-8

Thurber CS, Reagon M, Gross BL, Olsen KM, Jia Y, Caicedo AL (2010) Molecular evolution of shattering loci in U.S. weedy rice. Mol Ecol 19:3271-3284. https://doi.org/10.1111/j.1365-294X.2010.04708.x

Thurber CS, Hepler PK, Caicedo AL (2011) Timing is everything: early degradation of abscission layer is associated with increased seed shattering in US weedy rice. BMC Plant Biol 11:14-24. https:// doi.org/10.1186/1471-2229-11-14

Tseng TM, Burgos NR, Shivrain VK, Alcober EA, Mauromoustakos A (2013) Inter- and intrapopulation variation in dormancy of Oryza sativa (weedy red rice) and allelic variation in dormancy-linked loci. Weed Res 53:440-451. https://doi.org/10.1111/wre.12044

Veasey EA, Karasawa MGM, Santos PP, Rosa MS, Mamanie E, Oliveira GCX (2004) Variation in the loss of SD during after-ripening of wild and cultivated rice species. Ann Bot 94:875-882. https://doi.org/10. 1093/aob/mch215

Vidotto F, Ferrero A (2000) Germination behavior of red rice (Oryza sativa L.) seeds in field and laboratory conditions. Agronomie 20: 375-382. https://doi.org/10.1614/WT-D-10-00099.1

Vigueira CC, Olsen KM, Caicedo AL (2013) The red queen in the corn: agricultural weeds as models of rapid adaptive evolution. Heredity 110:303-311. https://doi.org/10.1038/hdy.2012.104

Wang X, Xia H, Wang W et al (2011) Transgenes for insect resistance reduce herbivory and enhance fecundity in advanced generations of crop-weed hybrids of rice. Evol Appli 4:672-684. https://doi.org/10. 1111/j.1752-4571.2011.00190.x

Wang JG, Miao W, Wang JY, Ma DR, Li JQ, Chen WF (2013) Effects of exogenous abscisic acid on antioxidant system in weedy and cultivated rice with different chilling sensitivity under chilling stress. J Agro Crop Sci 199(3):200-208. https://doi.org/10.1111/jac.12004

Watanabe H, Vaughan DA, Tomooka N (1998) Weedy rice complexes: case studies from Malaysia, Vietnam and Suriname. Int. Symp. on Wild and Weedy Rices in Agroecosystems, 10-11 Aug. Ho Chi Min City, Vietnam

Wen J, Ling J, Wen-Wei Z, Hu-Qu Z, Jian-Min W (2008) Mapping QTL for seed dormancy in weedy rice. Acta Agron Sin 34(5):737-742. https://doi.org/10.1016/S1875-2780(08)60028-0

Wirjahardja S, Guhardja E, Wiroatmodjo J (1983) Wild rice and its control. Proc. Weed Control Rice Conference, IRRI, Philippines
Xia HB, Xia H, Ellstrand NC, Yang C, Lu BR (2011) Rapid evolutionary divergence and ecotypic diversification of germination behavior in weedy rice populations. New Phytol 191:1119-1127. https://doi. org/10.1111/j.1469-8137.2011.03766.x

Xiong HB, Xu HY, Xu Q, Zhu Q, Gan SX, Feng DD, Zhang XL, Xie XD, Zhang H, Li J, Tan YL, Wen JC, Shi YM, Lee DS, Wei XH, Chen LJ (2012) Origin and evolution of weedy rice revealed by intersubspecific and inter-varietal hybridizations in rice. Mol Plant Breeding 10:131-139. https://doi.org/10.3969/mpb.010.000

Yadav SK (2010) Cold stress tolerance mechanisms in plants. A review. Agron Sustain Dev 30:515-527. https:/doi.org/10.1051/agro/ 2009050

Yamaguchi K, Ishihar K, Fukai S (2000) Biological control of rice weeds using fungal isolates. Wild and weedy rice in rice ecosystems in Asia-a review. Limited proceedings No. 2 Los Banos (Philippines): IRRI. 124p

Yan H, Ma L, Wang Z, Lin Z, Su J, Lu BR (2015) Multiple tissue-specific expression of rice seed-shattering gene $\mathrm{SH} 4$ regulated by its promoter pSH4. Rice 8(1):1. https://doi.org/10.1186/s12284-015-0047-4

Yang YY, Jung JY, Song WY, Suh HS, Lee Y (2000) Identification of rice varieties with high tolerance or sensitivity to lead and characterization of the mechanism of tolerance. Plant Physiol 124(3):1019 1026. https://doi.org/10.1104/pp.124.3.1019

Yang X, Wang F, Su J, Lu BR (2012) Limited fitness advantages of cropweed hybrid progeny containing insect-resistant transgenes (Bt/ CpTI) in transgenic rice field. PLoS One 7(7):e41220. https://doi. org/10.1371/journal.pone.0041220

Yao Y (2012) Studies on comprehensive productivity and use of sowing date and varieties of direct seeding rice in the lower Yangtze and Huai Valleys. Ph.D. thesis. Yangzhou University (in Chinese)

Ye H, Foley ME, Gu XY (2010) New seed dormancy loci detected from weedy rice derived advanced populations with major QTL alleles removed from the background. Plant Sci 179:612-619. https://doi. org/10.1016/j.plantsci.2010.04.003

Zhang WQ, Linscombe S, Webster E, Tan S, Oard J (2006) Risk assessment of the transfer of imazethapyr herbicide tolerance from clear field rice to red rice (Oryza sativa). Euphytica 152:75-86. https:// doi.org/10.1007/s10681-006-9180-x

Zhang SL, Li J, Lee DS, Xu HY, Zhang LD, Dongchen WH, XiongB H, Zhu Q, Zhang XL, Lu BR, Chen LJ (2014) Genetic differentiation of Asian weedy rice revealed with InDel markers. Crop Sci 54(6): 2499-2508. https://doi.org/10.2135/cropsci2014.01.0027

Zhu YQ, Ellstrand NC, Lu BR (2012) Sequence polymorphisms in wild, weedy and cultivated rice suggest seed-shattering locus sh4 played a minor role in Asian rice domestication. Ecol Evol 2:2106-2113. https://doi.org/10.1002/ece3.318

Ziska LH, Gealy DR, Tomecek MB, Jackson AK, Black HL (2012) Recent and projected increases in atmospheric $\mathrm{CO}_{2}$ concentration can enhance gene flow between wild and genetically altered rice (Oryza sativa). PLoS One 7(5):e37522. https://doi.org/10.1371/ journal.pone. 0037522

Ziska LH, Gealy DR, Burgos N, Caicedo AL, Gressel J, Lawton-Rauh AL, Avila LA, Theisen G, Norsworthy J, Ferrero A, Vidotto F (2015) Weedy (red) rice: an emerging constraint to global rice production. Adv Agron 129:181-228. https://doi.org/10.1016/bs.agron. 2014.09.003 